\title{
Burkitt Leukemia
}

National Cancer Institute

\section{Source}

National Cancer Institute. Burkitt Leukemia. NCI Thesaurus. Code C7400.

The leukemic counterpart of Burkitt's lymphoma. The characteristic Burkitt cells are seen

in the bone marrow and the peripheral blood. This is an aggressive leukemia. 